\title{
Screening and Prevention of Nosocomial Infections in Neonatal Intensive Care Unit (NICU)
}

\author{
Roqaiah M. Al-Jabri'1, Ahmed M. Al-Hejin 1,2, Rukaia Gashgari' ${ }^{3}$, Noor Mohammed Bataweel1,2, Mohamed \\ Abu-Zaid1,4, Maged Mostafa Mahmoud ${ }^{2,5}$, Azhar Abdullah Najjar',2, Mohamed Morsi M. Ahmed1,6 \\ 1Department of Biological Sciences, Faculty of Science, P.O. Box 80203, King Abdulaziz University, Jeddah, 21589, Saudi Arabia. \\ ${ }^{2}$ King Fahad Medical Research Center, P.O. Box 80216, King Abdulaziz University, Jeddah, 21589, Saudi Arabia. \\ 3Department of Biological Sciences, Faculty of Science, P.O. Box 80327, Jeddah University, Jeddah, 21589, Saudi Arabia. \\ ${ }^{4}$ Microbial Genetics Department, Genetics Engineering and Biotechnology Division, National Research Center, Dokki, Giza, Egypt. \\ ${ }^{5}$ Molecular Genetics and Enzymology Department, Human Genetics and Genome Research, National Research Center, Cairo, Egypt. \\ ${ }^{6}$ Nucleic Acids Research Dept., Genetic Engineering, and Biotechnology Research Institute (GEBRI), City for Scientific Research and Technological \\ Applications. Alexandria, Egypt.
}

Correspondence Author: Roqaiah M. Al-Jabri, Department of Biological Sciences, Faculty of Sciences, P.0. Box 80203, King Abdulaziz University, Jeddah City, 21589, Kingdom of Saudi Arabia.

Received date: 12 November 2018, Accepted date: 10 January 2019, Online date: 25 January 2019

Copyright: (C) 2019 Roqaiah M. Al-Jabri et al., This is an open-access article distributed under the terms of the Creative Commons Attribution License, which permits unrestricted use, distribution, and reproduction in any medium, provided the original author and source are cre dited.

\begin{abstract}
Infants in neonatal intensive care units (NICUs) are usually immunocompromised. So, healthcare-associated infections (HAIs), also known as, nosocomial infections, consider a severe issue for infants in neonatal intensive care units (NICUs). HAIs are described as onset more than 48 hours after hospital admission. In fact, it is responsible for the increase of mortality, morbidity and the duration of stay in the hospital. The rate of HAIs in NICU is range from $6 \%$ to $50 \%$ per admission. However, this rate rises by 3 to 20 -fold in developing countries as contrasted to developed countries. Also, about 2.9 million newborns die yearly during the initial 28 days of their life. Importantly, the environment that surrounds the patients is full by equipment for organ support and monitoring e.g., ventilator, monitors, extracorporeal life support machines. Moreover, the bacteria infectious may come from different resources (e.g., people in the hospital, healthcare' hands, on equipment or surfaces). In fact, HAIs regularly rise as a result of the formation of biofilms at the surfaces of these medical devices. The most gram-positive bacteria that because HAIs are Group B Streptococci, Listeria, Staphylococcus aureus, Methicillin-resistant S. aureus (MRSA). As for gram-negative bacteria such as Escherichia coli, Enterobacter, Klebsiella, Pseudomonas, Serratia, Salmonella...etc., some of these bacteria are resistance for most of the antibiotics. World Health Organization (WHO) put many infection control techniques that may help to reduce the nosocomial infections. Therefore, this review aims to highlight and give brief information about the problem of healthcare-associated infections in NICU and the methods of environmental decontamination in hospitals.
\end{abstract}

Key words: Microbial, Microbiota, neonatal, infections, NICU, Nosocomial Infections, HAIs.

\section{INTRODUCTION}

Neonatal Intensive Care Unit (NICU) is a selected place of a hospital that usually has new-born infants who require high of medical attention [1]. In the United States, more than 300,000 babies enter into neonatal intensive care units (NICU) every year [2]. Although using many different infection control techniques, the new-borns' mortality has increased. Every year, about 2.9 million newborns die during the initial 28 days of their life [2], [3]. The reason behind that is the infants in NICUs are usually immunocompromised. Consequently, they are generally at a high level of danger for having nosocomial infections (hospitalacquired infections) [4]. Whereas about 1 million neonatal death every year globally because of neonatal infections [5]. Neonates who get nosocomial infections have greater than three times danger of losing their life as compared to those who do not have infections [6].

One of the most causes of patient morbidity and mortality is device-associated healthcare-acquired diseases (DA-HAIs), which is capable of prolonging the length of stay in the intensive care unit (ICU) [7]. Many researches demonstrated that healthcareassociated pathogens repeatedly contaminate the patient's environment. This environment includes both porous surfaces ex: towels and nonporous, hard surfaces ex: table [8]. Whereas, these contaminated surfaces can transmit of pathogens by directly way by 
contacting the patient with the surroundings or indirectly way through contamination the hands of healthcare workers. So, it should reduce the surface infection and eliminate of those organisms through cleaning and disinfection practices reduces this risk [9].

Therefore, this review aims to discuss the nosocomial infections in neonatal intensive care unit NICU and the disinfection methods in the hospital area.

\section{Differences between the care in ICU and other hospital units}

1- patients with critical health conditions need:

- intensive observation and monitoring.

- Nurses with specific skills to care for one or two patients at a time.

- $\quad$ ICU doctors who are mainly skilled for critical care doctors.

2- Depending on the patient health condition, they may need special equipment in their room. For example, patients are linked to machines to monitor their heart, blood pressure, and respiratory rate. Also, some patients need ventilators (breathing machines) to assist them to breathe until they can breathe on their own [10].

\section{3- levels of babies' care in a hospital:}

- Special care baby unit (SCBU)

It is also called a special care unit (SCU). Those offers the simplest stage of care for babies and stabilize a baby's state before transporting them to a different unit or giving them emergency care if necessary. Additionally, they may receive infants from other units when they are healthy [11].

\section{- $\quad$ Local neonatal unit (LNU)}

This unit offers unique care for infants of their local region. However, it is not included very sick babies and who need long time or high level of care. Most of the babies whom above 27 weeks of gestation will have complete care, which includes short durations of intensive care, inside LNU [11].

\section{- $\quad$ Neonatal intensive care unit (NICU)}

This level is specialist and has the centers to care for premature infants with critical condition. It offers a complete variety of neonatal medical care for babies [11].

\section{Factors that may increase the chance for babies to be admitted to the NICU}

\section{Prematurity}

Babies born early (much less than 37 weeks) is the most cause of NICU admission. Premature babies do not have a developed body, and they are not able to transition to the normal outside environment compared to full-term babies. Moreover, they cannot control their body temperature and frequently have extreme weight loss and risky essential signs and symptoms. These infants require to stay in controlled, enclosed surroundings environment called an isolette or incubator, which gives warmness to keep steady body temperature and imitate the uterine environment [12].

\section{Respiratory Distress Syndrome (RDS)}

The infants have immature lungs, so RDS considers as one of the most common respiratory problems among them [12].

\section{Sepsis or infection}

Sepsis or infection is the main reason for neonatal death. Premature infants are more exposed to infections more than full-term infants because of their weak immune system [12].

\section{Hypoglycemia}

It is also called low blood sugar. The premature infants and infants born to a mom with gestational diabetes are more exposed to hypoglycemia than others [12].

\section{Maternal chorioamnionitis}

One of the reasons that make a baby enter to the NICU is the mother's health. Before or during labor, the mother who has inflammation of the placenta, maternal chorioamnionitis, and the umbilical cord, her baby should be admitted to the NICU after delivery and started on antibiotics for as a minimum 48 hours before leaving the hospital [12].

\section{Procedures and Equipment in the NICU}

The following list includes some of monitoring equipment that usually used in the NICU [11] (Figure 1): 

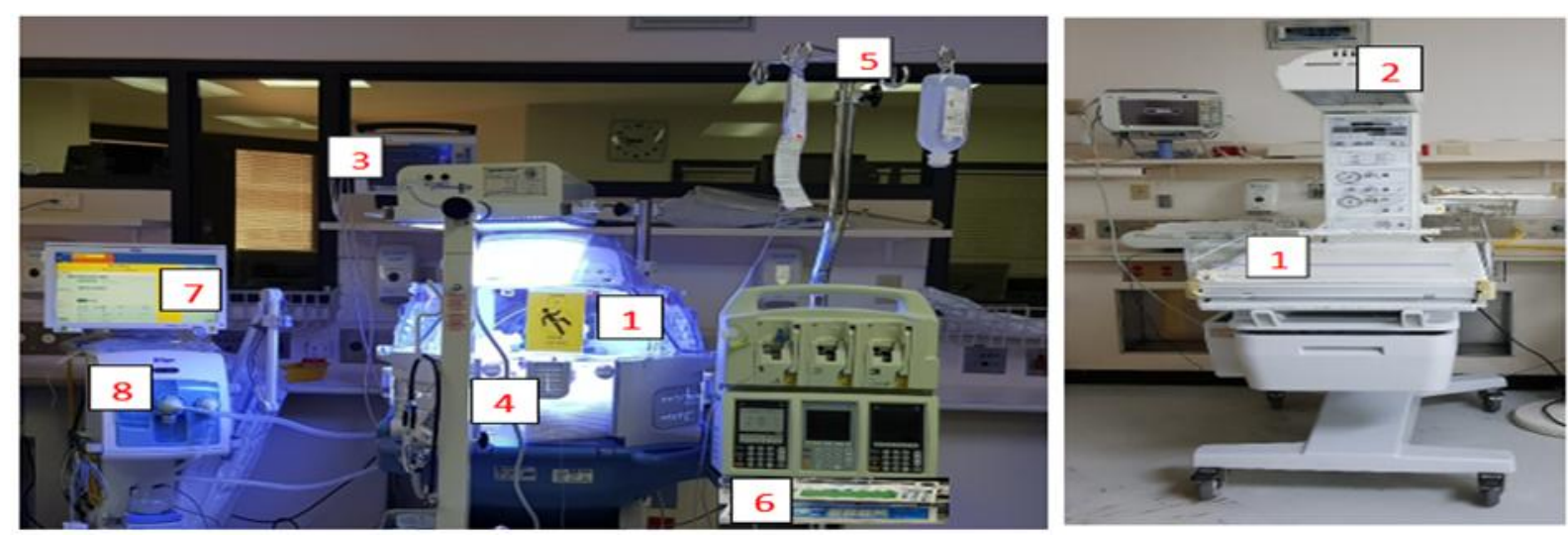

Figure 1: Some of the equipment in the Neonatal intensive care unit (NICU). (NICU, King Abdulaziz University hospital, Jeddah, Saudi Arabia)

\section{(1) Incubator}

A transparent box to maintain the baby warm. It could be open or closed.

\section{(2) Overhead heater:}

It is a heater, used when the incubator is open. It helps to be sure the temperature of the baby is appropriate.

(3) Monitors:

They help to test the baby's heart rate, blood pressure, temperature, heart rate, breathing rate and the amount of gases ex: $\mathrm{O}_{2}$, $\mathrm{CO}$ ${ }_{2}$ in the blood. Moreover, when the baby has apnoea, these monitor machines give an alarm to the staff.

\section{(4) Ambient oxygen analyzer:}

It is small equipment in the incubator. It assists in measuring the oxygen in the air and making sure it is sufficient.

(5) Intravenous (IV) drip:

Through this narrow tube and needle, the infant can receive fluids, nutrients, and medicinal drug.

(6) Feeding pump and tubes:

The nutrients are passed through flexible plastic tubes. The baby may have one, or all, of: a nasogastric tube, an orogastric tube, and a transpyloric tube.

(7) Ventilator monitor:

All the ventilator settings are displayed on a monitor.

\section{(8) Ventilator:}

In NICU, some babies need a ventilator to help them to breathe. It has a tube enter into their throat or nose.

\section{Hospital-Acquired Infections in NICU}

In the ICU, the increase in mortality, morbidity and the duration of stay in the hospital is related to nosocomial contamination (described as onset more than forty-eight hours after hospital admission) [13]. So, patients in ICUs are usually at extreme risk of getting infections in order to their diseases, impaired immunity, and exposure to many invasive [14], [15], [16],[17]. The rate of HAI spreading in ICU is higher than in general wards of a hospital by 5-10 [18], [17].

As for infants in neonatal intensive care units (NICUs), specifically, ones who have gone through surgery or have congenital abnormalities, are usually immunocompromised. Consequently, they are usually at a high level of danger for having nosocomial infections (hospital-acquired infections) [19], [20], [21],[22].

Therefore, although in using many different infection control techniques like prophylactic antibiotics, immunoglobulins, and physical obstacles, the new-borns' mortality has continued extremely high. Every year, about 2.9 million newborns die during the initial 28 days of their life [23], [24].

Healthcare-associated infections (HAIs) cause concern in NICUs because of the improvement in healing and diagnostic techniques and expanded duration of preterm babies. Prior studies have proven that the average of nosocomial infection in NICUs range from $8.7 \%$ to $74.3 \%$. In the literature, the rate of HAIs is range from $6 \%$ to $50 \%$ per admission. However, this rate rises by 3 to 20 -fold in developing countries as contrasted to developed countries [25], [26].

\section{Types of babies' infections \\ Early-onset (EO) infections}

These infections take place in the first 2-3 days after birth. They usually happen as a result of moving of pathogens from the mother to baby during or just before delivery [27]. So, maternal vaginal bacterial flora is the most common source of pathogens that cause EO infections [56].

The rate of morbidity is about $\sim 1-2$ per a thousand of neonatal, however, mortality rate reaches to $\sim 3 \%$ amongst terms newborns, and $\sim 16 \%$ in very-low-birth-weight (VLBW) babies [56], [57],[58],[59]. 
The most pathogens that cause EO infections are bacteria. Streptococcus agalactiae and Escherichia coli are the most common agents, followed by Streptococcus pyogenes, Listeria monocytogenes, Viridians streptococci, Haemophilus influenza, Streptococcus pneumoniae, Pseudomonas aeruginosa, Staphylococcus (S.) aureus, and Enterococci [56].

\section{- $\quad$ Late-onset (LO) neonatal infections}

They are infections that take place after 48 - 72 hours of birth. LOS is caused by microorganisms obtained from the environment after the birth (nosocomial community-acquired infections) [27].

They associated with extended hospitalization, mechanical ventilation, and use of many devices, which all are factors led to LOS [56].

According to NICHD Neonatal Research Network data, Gram-positive bacteria are cause LOS for about 70\%. However, CoNS are the most frequent pathogens, followed by S. aureus, Enterococcus species, and GBS. As for Gram-negative organisms, they cause $18 \%$ of LOS [56]. Preterm infants especially if VLBW is at a maximum degree of danger of LO infections due to their immune deficiencies [27].

\section{Bacterial infections in NICU}

Usually after 48 - 72 hours of patients admitted to ICU, the colonization of nosocomial organisms occurs between them [13]. Whereas that the spread of hospital-acquired infections (HAIs) in Europe ranges from 3.5\% to 10\%. The most of HAIs are urinary tract infections (UTIs), surgery-related infections, pneumonia, and primary sepsis [27], [28].

As previously mentioned, newborns enter to intensive care units (ICUs) are at high risk of developing nosocomial infections (NIs); due to their illness and exposure to invasive medical devices and the presence of multi-resistant microorganisms [28], [29], [30].

The nosocomial infections (NIs) in very low birth weight (VLBW) babies increase in 15\% to 25\% [31],[32],[30]. Other statistic s have found that neonatal infections cause about 1 million deaths every year globally. The varies occurrence is from 5 to 170 per 1000 live births, and it spread in countries with low or middle income [30].

One of the primary reasons that cause infections in different sections of ICUs is bacteria. The nosocomial microorganisms are not similar those within the community, with a high rate of resistant organisms. So, antibiotic resistance considers as one of the most pressing global health problems, which ends up in increased morbidity, mortality, and healthcare fees [33].

The fast increase in multidrug-resistant MDR bacterial strains become observed, which can be due to the bad carried out programs [34], [33]. Patients immoderate use of antibiotics, whether on their personal or inside the hospital which is the primary source for the emergence of resistant traces [35], [33]

\section{The reasons for antimicrobial resistance bacteria emergence in ICU}

- Misusing of antibiotic use led to the evolution of resistance in existing bacteria.

- $\quad$ contacting with healthcare workers or via procedures.

In the ICU, the increase of resistant microorganisms is related to poorer outcomes. Those resistant microorganisms include vancomycin-resistant Enterococci (VRE), methicillin-resistant Staphylococcus aureus (MRSA) and multi-drug resistant (MDR) Gram-negatives [13].

\section{The sources and the ways of transmission of hospital-acquired infections}

Healthcare-related infections are a severe issue for neonatal intensive care units. Moreover, knowing the sources of the infection factors and the ways of transmission is one of the most significant approaches of saving NICU and stopping health center acquired Infections (HAIs).

The environment that surrounds the patients is full of equipment for organ support and monitoring). So, the bacteria infectious may come from different resources (e.g., people in the hospital, healthcares' hand, on equipment or surfaces). HAIs regularly rise up as a result of the formation of biofilms at the surfaces of these medical devices [36], [30].

\section{Contamination of inanimate surfaces by bacteria colonizing may occur as}

- The direct transfer of bacteria from patients.

- $\quad$ The healthcare workers'(HCWs') hands.

Therefore, HCWs' hands contaminate frequently from inanimate surfaces and direct contact with patients [37], [38].

\section{The healthcare area and patient zone}

The ideas of the healthcare area and patient zone were included as a consumer-focused, effective behaviour that aims to improve hand cleanliness [39], [38].

The patient zone includes the patient, surfaces, and devices that around him (i.e., monitors, bed rails, ventilator) [38]. As for healthcare area, it consists of all surfaces outdoor of the patient zone [40],[38] . Bacteria can contaminate it from different person zones [38]. 


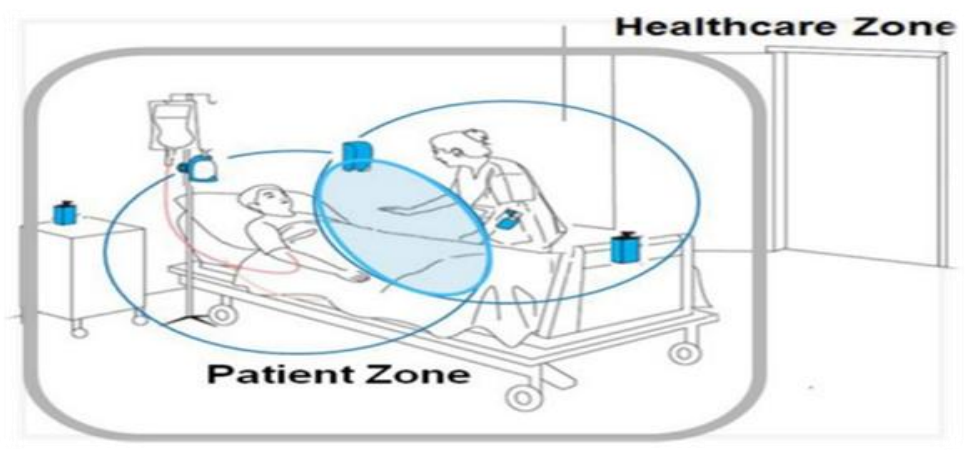

Figure 2: The patient zone \& healthcare area (Hostiuc, Molnar et al. 2018)

In ICU, the environmental contamination includes both equipment which near to patients, and used for their care (e.g., ultrasoundequipment, stethoscopes, surfaces of mechanical ventilators) and the surfaces of items used for data recordings (i.e., medical charts, mouse, and computer keyboard) [40], [38].

So, knowing the mechanisms behind the transmission of pathogens from surfaces of devices may contributions to put the rules of contamination control which aims to stop the extent of healthcare-associated infections [38]

The factors of the capacity of the nosocomial pathogens to live on inanimate surfaces and equipment even after cleansing techniques

- The particular microorganism characteristics (which includes genus, species, a particular strain, and microorganism density).

- The factors of environment (such as humidity, temperature, floor type, and UV radiation) [41],[42],[38].

There are studies suggested some proofs on the ability of bacteria to live on in environmental $C$. difficile, VRE, MRSA, P. aeruginosa , Escherichia coli, Klebsiella spp., and Acinetobacter spp [43], [38]. CoNS are capable of surviving up to 8 to 21 days on cotton which use to made clothing. Moreover, distinct species from the same genus showed different survival capacity [38], [44]. For instance, C. parapsilosis proved higher resistance as compared to C. albicans or C. krusei [45], [38]. P. aeruginosa lives for best 2-24 hours on the floor [38], [44].

Importantly, some of the essential microbic structures cause resistance against disinfectants. For example, a waxy cell wall in mycobacteria which capable of preventing disinfectants access, whereas an outer membrane-actin gas in Gram-poor microorganism make a barrier to prevent the uptake of disinfectants [46], [38].

\section{Prevention of nosocomial infection \\ Reducing person-to-person transmission}

\section{- Hand decontamination}

Hands an essential role in the transmission of hospital infections [47], [48], and it can be reduced with appropriate hand hygiene [47], [49],[50],[51].

\section{Requirements for optimal hand hygiene [47]}

- Running water and high quality of soap.

- Clean facilities for drying (disposable towels is highly recommended).

- Using hand disinfectants.

\section{- Personal hygiene}

All health staff must maintain good personal hygiene. Nails, beard, mustaches, and hair must be kept short and clean. However, the hair also could be pinned up [47].

\section{- Clothing}

Uniform trousers and a short-sleeved gown are highly required for healthcare staff, especially who work in intensive care unit [47].

\section{- Masks and gloves}

The staff wears masks and gloves for protecting themselves, especially when they care patients with airborne infections or communicable disease transmitted by contact. Moreover, wearing masks and gloves for staff can protect patients, especially immuno-compromised patients [47].

\section{Preventing transmission from the environment}

As we mentioned before, one the most causes of patient morbidity and mortality is device-associated healthcare-acquired diseases (DA-HAIs), which is capable for prolonging the length of stay in the intensive care unit (ICU). Also, the increase of clinical costs especially in developing countries, where rates have been appeared to be much higher than in high-income countries [46], [52].

Several types of research demonstrate that the patient's environment is regularly contaminated with healthcare-associated pathogens. This environment includes both pored surfaces ex: towels and non-pored, hard surfaces ex: table [53], [54], [55] . 
Contaminated surfaces consider as reservoir pathogens which transfer directly through the patient when contact with the surroundings or indirectly through contamination of healthcare workers' hands and gloves [56]. So, it should reduce the surface infection and eliminate of those organisms through thorough cleaning and disinfection practices reduces this risk [57], [58], [56].

In fact, following an effective and completed infection manage program centered on DA-HAI surveillance has appeared to be successful in several studies conducted in the US, proposing that the rate of DA-HAI can be diminished by as much as 30\% [59].

\section{Classifying the danger of infection}

Equipment is classified into three types by how invasive it at some stage of normal use [41]:

1. low-risk items - objects are non-critical. They in contact with normal, healthy skin e.g., blood pressure cuff. low-stage of disinfection is enough.

2. Middle-risk items - They are semi-critical. They are near to contact with non-healthy skin or mucous layers e.g., endoscopes. This type has also low-risk items which may become contaminated by organisms. They require cleaning and high level of disinfection.

3. High-risk items - These items are also called critical items, that enter to sterile tissue by penetrating pores and health skin e.g., anaesthesia needles, vascular catheters). They should be sterile.

\section{Decontamination}

It is a process provides a reusable medical device for further use. It is a combination of either cleaning and sterilization or cleaning and disinfection. It is recommended that all reusable medical items, except the low-risk items, should be followed by a sterile services department (SSD) [41].

\section{Cleaning}

It is a physical process for the elimination of foreign material from an object. It is the primary step of decontamination [41].

\section{Cleaning can be}

\section{- Manual}

Manual cleaning of tools is done by using a warm detergent solution. The best temperatures for the water are around $35^{\circ} \mathrm{C}$, that causes denaturation of protein deposits; then it develops a protective layer of microorganisms [41].

\section{- Mechanical cleaning}

These approaches have high-quality management and able to save the surgeon from exposure to chemical compounds and biohazards. The conventional mechanical cleaning techniques are ultrasonic cleaners and hot water disinfectors which form a part of an automated decontamination technique [41].

\section{Disinfection}

It is a process for eliminate of many or all pathogenic organisms on an item. However, it does not destroy spores of bacteria [41].

\section{Disinfection methods}

\section{Thermal disinfection}

\section{- Hot water disinfectors}

It is a combination of mechanical cleaning and heat disinfection. Combination of heat disinfection and mechanical cleaning. It is a combination of mechanical cleaning and heat disinfection. It is appropriate for items that can resist for frequent exposure moist heat. Water temperatures run in cycles from $65^{\circ} \mathrm{C}$ to $90^{\circ} \mathrm{C}[41]$.

\section{- Pasteurization}

It uses saturated steam below atmospheric. The pressure is being at temperatures around $75^{\circ} \mathrm{C}$ for $10-30$ minutes [41].

\section{Chemical disinfection}

Chemical compounds are an opportunity way to disinfect heat-sensitive device [41].

\section{Chemicals may be divided into}

\section{- Low-level disinfectants:}

As for bacteria, these chemicals can break the vegetative bacteria but not endospores of them. They include chlorhexidine $70 \%$ alcohol, sodium hypochlorite, and iodophor [41].

\section{- High-level disinfectants:}

These chemicals usually use for sterilization, and they destroy all vegetative bacteria, and the spores of bacteria. These include super-oxidized water, aldehydes, hydrogen peroxide chlorine dioxide, and peracetic acid [41]: 
Table 1: Some examples of common high-level disinfectants which use for disinfection and sterilization. (Wilson and Nayak 2013)

\begin{tabular}{|c|c|c|}
\hline \multirow{2}{*}{ Disinfectant } & \multicolumn{2}{|c|}{ Approximate duration of exposure } \\
\cline { 2 - 3 } & High-Level disinfection & Sterilization \\
\hline$>2 \%$ Glutaraldehde & $20-90$ minutes & 10 hours \\
\hline $7.5 \%$ Hydrogen peroxide & 30 minutes & 6 hours \\
\hline$>0.2 \%$ Peracetic acid at $50-55^{\circ} \mathrm{C}$ & Not indicated & 12 minutes \\
\hline $0>55 \%$ Orthophthaldehyde & 12 minutes & Not indicated \\
\hline Super-oxidized water $(650-675$ ppm active free chlorine) & 10 minutes & Not indicated \\
\hline
\end{tabular}

\section{UV radiation}

It uses to kill airborne and organisms on surfaces [41].

\section{Sterilization}

It is any method used to make an item unoccupied from all living microorganisms.

Sterilization may be done through these methods [41]:

\section{Thermal sterilization}

\section{- Steam sterilization (autoclave):}

Items expos to cycles of temperature and saturated steam. The cycles consisted of $121{ }^{\circ} \mathrm{C}$ for 15 minutes or $134{ }^{\circ} \mathrm{C}$ for 3 minutes [41].

\section{- Dry, hot air}

Oven uses for sterilization of items by hot, dry air at $160{ }^{\circ} \mathrm{C}$ for around 2 hours. It uses instead of steam sterilization; however, it is not recommended in hospitals [41].

\section{Chemical sterilization}

The following strategies may be used [41]:

- $\quad$ Ethylene oxide (ETO).

- Hydrogen peroxide gas plasma.

\section{Radiation}

During the manufacture of one-use items e.g., face masksand, needles...etc., Gamma radiation usually use for sterilizing [41].

\section{CONCLUSION}

With increasing the rate of mortality and morbidity of infants in neonatal intensive care units (NICUs), nosocomial infections began to consider as a global problem. However, by practicing of efficient disinfections in hospitals, it can help to provide new control programs of devise infection field. Therefore, the pathogens can be reduced easily. Moreover, making healthcare worker and public aware of the danger of these infections can also help in the reduction of nosocomial infections in NICU and other sections of hospitals.

\section{CONFLICT OF INTEREST}

The authors declare no conflicts of interest.

\section{ACKNOWLEDGMENT}

This work support from King Abdulaziz City for Sciences and Technologies (KACST) in the Saudi Arabia, and thanks to the King Abdulaziz University hospital, Jeddah, Saudi Arabia. The authors also, acknowledge assistance from the Science \& Technology Unit, Deanship of Scientific Research and Deanship of Graduate Studies, and also, acknowledge support from the Dept. of Biological Sciences, Faculty of Science, King Abdulaziz University (KAU), Jeddah, KSA.

\section{REFERENCES}

1. https://www.stanfordchildrens.org/en/topic/default?id=the-neonatal-intensive-care-unit-nicu-90-P02389. 2018

2. Stroustrup A, Bragg J, Andra S, Curtin P, Spear E, Sison D, Just A, Arora M, Gennings C, 2018. Neonatal intensive care unit phthalate exposure and preterm infant neurobehavioral performance. PLoS One 13(3):e0193835.

3. Chen Y, Lin C, Rehn Y, Chen J, Chen P, Chen C, Wang T, Huang F, 2017. Reduced nosocomial infection rate in a neonatal intensive care unit during a 4-year surveillance period. J Chin Med Assoc 80(7):427-431.

4. Stover B, Shulman S, Bratcher D, Brady M, Levine G, Jarvis W, 2001. Nosocomial infection rates in US children's hospitals' neonatal and pediatric intensive care units. Am J Infect Control. 29(3):152-157. 
5. Hostiuc S, Molnar A, Moldoveanu A, Aluas M, Moldoveanu F, Bocicor I, Dascalu M, Badila E, Hostiuc M, Negoi I. 2018. Patient autonomy and disclosure of material information about hospital-acquired infections. Infect Drug Resist 11: 369375.

6. Seki M, Machida H, Yamagishi Y, Yoshida H, Tomono K, 2013. Nosocomial outbreak of multidrug-resistant Pseudomonas aeruginosa caused by damaged transesophageal echocardiogram probe used in cardiovascular surgical operations. J Infect Chemother. 19(4):677-681.

7. Empaire G, Guzman Siritt M, Rosenthal V, Perez F, Ruiz Y, Diaz C, Di Silvestre G, Salinas E, Orozco N. Multicenter prospective study on device-associated infection rates and bacterial resistance in intensive care units of Venezuela: International Nosocomial Infection Control Consortium (INICC) findings. Int Health. 2017; 9(1):44-49.

8. Han J, Sullivan N, Leas B, Pegues D, Kaczmarek J, Umscheid C, 2015. Cleaning Hospital Room Surfaces to Prevent Health Care-Associated Infections: A Technical Brief. Ann Intern Med. 163(8):598-607.

9. Allen M, Hall L, Halton K, Graves N, 2018. Improving hospital environmental hygiene with the use of a targeted multimodal bundle strategy. Infection, Disease \& Health, 23(2): 107-113.

10. http://www.cpmc.org/learning/documents/icu-ws.html.2018

11. https://www.tommys.org/pregnancy-information/pregnancy-complications/premature-birth/your-babys-timehospital/neonatal-intensive-care-unit-nicu.2018

12. https://www.unitypoint.org/livewell/article.aspx?id=0f9e4fe7-eb43-4235-a30a-f5853feb23f1.2018/",

13. Trubiano J, Padiglione A. 2015; Nosocomial infections in the intensive care unit. Anaesthesia \& Intensive Care Medicine 16(12): 598-602.

14. Dettenkofer M, Ebner W, Els T, R Babikir R, Lucking C, Pelz K, Ruden H, Daschner F, 2001. Surveillance of nosocomial infections in a neurology intensive care unit. J Neurol. 248(11):959-964.

15. Ylipalosaari P, Ala-Kokko T, Laurila J, Ohtonen P, Syrjala H. Intensive care acquired infection is an independent risk factor for hospital mortality: a prospective cohort study. Crit Care. 2006; 10(2):R66.

16. Aly N, Al-Mousa H, Al Asar el S. Nosocomial infections in a medical-surgical intensive care unit. Med Princ Pract. 2008; 17(5):373-377.

17. Cornejo-Juarez P, Vilar-Compte D, Perez-Jimenez C, Namendys-Silva S, Sandoval-Hernandez S, Volkow-Fernandez P. 2015. The impact of hospital-acquired infections with multidrug-resistant bacteria in an oncology intensive care unit. Int $\mathbf{J}$ Infect Dis 31: 31-34.

18. Weinstein R, 1998. Nosocomial infection update. Emerg Infect Dis 4(3): 416-420.

19. Stover B, Shulman S, Bratcher D, Brady M, Levine G, Jarvis W, 2001. Nosocomial infection rates in US children's hospitals' neonatal and pediatric intensive care units. Am J Infect Control. 29(3):152-157.

20. Urrea M, Iriondo M, Thio M, Krauel X, Serra M, LaTorre C, Jimenez R, 2003. A prospective incidence study of nosocomial infections in a neonatal care unit. Am J Infect Control, 31(8):505-507.

21. Couto R, Carvalho E, Pedrosa T, Pedroso E, Neto M, Biscione F, 2007. A 10-year prospective surveillance of nosocomial infections in neonatal intensive care units. Am J Infect Control. 35(3):183-189.

22. Hewitt K, Mannino F, Gonzalez A, Chase J, Caporaso J, Knight R, Kelley S. 2013. Bacterial diversity in two Neonatal Intensive Care Units (NICUs). PLoS One 8(1): e54703.

23. Chen Y, Lin C, Rehn Y, Chen J, Chen P, Chen C, Wang T, Huang F, 2017. Reduced nosocomial infection rate in a neonatal intensive care unit during a 4-year surveillance period. J Chin Med Assoc 80(7): 427-431.

24. Stroustrup A, Bragg J, Andra S, Curtin P, Spear E, Sison D, Just A, Arora M, Gennings C, 2018. Neonatal intensive care unit phthalate exposure and preterm infant neurobehavioral performance. PLoS One 13(3): e0193835.

25. Gadallah M, Aboul Fotouh A, Habil, I, Imam S, Wassef G. 2014. Surveillance of health care-associated infections in a tertiary hospital neonatal intensive care unit in Egypt: 1-year follow-up. Am J Infect Control. 42(11):1207-1211.

26. Kumar S, Shankar B, Arya S, Deb M, Chellani H, 2018. Healthcare associated infections in neonatal intensive care unit and its correlation with environmental surveillance. J Infect Public Health 11(2): 275-279.

27. Vergnano S, Heath P, 2013. Fetal and neonatal infections. Medicine 41(12): 723-729.

28. Ott E, Saathoff S, Graf K, Schwab F, Chaberny I, 2013. The prevalence of nosocomial and community acquired infections in a university hospital: an observational study. Dtsch Arztebl Int 110 (31-32): 533-540.

29. Zingg W, Holmes A, Dettenkofer M, Goetting T, Secci F, Clack L, Allegranzi B, Magiorakos A, Pittet D, 2015. Hospital organisation, management, and structure for prevention of health-care-associated infection: a systematic review and expert consensus. Lancet Infect Dis 15(2): 212-224.

30. Hostiuc S, Molnar A, Moldoveanu A, Aluas M, Moldoveanu F, Bocicor I, Dascalu, M, Badila E, Hostiuc M, Negoi I., 2018. Patient autonomy and disclosure of material information about hospital-acquired infections. Infect Drug Resist 11: 369375.

31. Pronovost P, Weast B, Bishop K, Paine L, Griffith R, Rosenstein B, Kidwell R, Haller K, Davis R, 2004. Senior executive adopt-a-work unit: a model for safety improvement. Jt Comm J Qual Saf 30(2): 59-68.

32. Merle V, Van Rossem V, Tavolacci M, Czernichow P, 2005. Knowledge and opinions of surgical patients regarding nosocomial infections. J Hosp Infect 60(2): 169-171.

33. Al Yousef S, 2016. Surveillance of Antibiotic-Resistant Bacteria in King Khalid Hospital, Hafr Al-Batin, Saudi Arabia, During 2013. Jundishapur J Microbiol 9(9): e19552.

34. Levy S. 2002. The 2000 Garrod lecture. Factors impacting on the problem of antibiotic resistance. J Antimicrob Chemother 49(1): 25-30. 
35. Bacon D, Alm R, Burr D, Hu L, Kopecko D, Ewing C, Trust T, Guerry P, 2000. Involvement of a plasmid in virulence of Campylobacter jejuni 81-176. Infect Immun 68(8): 4384-4390.

36. Herwaldt L. 1996. Ethical Aspects of Infection Control. Infection Control and Hospital Epidemiology 17(2): 108-113.

37. Hayden M, Blom D, Lyle E, Moore C, Weinstein R, 2008. Risk of hand or glove contamination after contact with patients colonized with vancomycin-resistant enterococcus or the colonized patients' environment. Infect Control Hosp Epidemiol 29(2): 149-154.

38. Russotto V, Cortegiani A, Fasciana T, Iozzo P, Raineri S, Gregoretti C, Giammanco A, Giarratano A. 2017. What Healthcare Workers Should Know about Environmental Bacterial Contamination in the Intensive Care Unit. Biomed Research International.

39. Sax H, Allegranzi B, Uckay I, Larson E, J. Boyce J, Pittet D. 2007. My five moments for hand hygiene': a user-centred design approach to understand, train, monitor and report hand hygiene. $\mathrm{J}$ hospital ifect 67(1): 9-21.

40. Russotto V, Cortegiani A, Raineri S, Giarratano, A. 2015. Bacterial contamination of inanimate surfaces and equipment in the intensive care unit. J Intensive Care 3: 54

41. Wilson A, Nayak S. 2013. Disinfection, sterilization and disposables. Anaesthesia \& Intensive Care Medicine 14(10): 423427.

42. Esteves D, Pereira V, Souza J, Keller R, Simoes R, Winkelstroter Eller L, Rodrigues M. 2016. Influence of biological fluids in bacterial viability on different hospital surfaces and fomites. Am J Infect Control 44(3):311-314.

43. Hota B. 2004. Contamination, disinfection, and cross-colonization: are hospital surfaces reservoirs for nosocomial infection? Clin Infect Dis 39(8): 1182-1189.

44. Kramer A, Schwebke I, Kampf G. 2006. How long do nosocomial pathogens persist on inanimate surfaces? A systematic review. BMC Infect Dis 6: 130.

45. Neely A, Orloff M. 2001. Survival of some medically important fungi on hospital fabrics and plastics. J Clin Microbiol 39(9): 3360-3361.

46. Russell A. 1999. Bacterial resistance to disinfectants: present knowledge and future problems. J Hosp Infect 43 Suppl: S5768.

47. World Health Organization Prevention of hospital-acquired infections: a practical guide World Health Organization, Geneva, 2002. [Online] Available from: http://www.who.int/csr/resources/publications/whocdscsreph200212.pdf [Accessed on 10th December, 2018]

48. Bouvet E. 1993. Risk for health professionals of infection with human immunodeficiency virus. Current knowledge and developments in preventive measures. Médecine et Maladies Infectieuses 23:28-33.

49. Health Canada, 1997. An integrated protocol to manage health care workers exposed to bloodborne pathogens. Can Commun Dis Rep 23 Suppl 2: i-iii, 1-14; i-iii, 1-16.

50. Health Canada, 1997. Preventing the transmission of bloodborne pathogens in health care and public services. Can Commun Dis Rep, 23 Suppl 3: i-vii, 1-43; i-vii, 1-52.

51. 1997. Management of healthcare workers infected with hepatitis B virus, hepatitis C virus, human immunodeficiency virus, or other bloodborne pathogens. AIDS/TB Committee of the Society for Healthcare Epidemiology of America. Infect Control Hosp Epidemiol 18(5):349-63

52. Rosenthal, V, Jarvis W, Jamulitrat S, Silva C, Ramachandran B, Dueñas L, Gurskis V, Ersoz, Novales G, Khader I. 2012. Socioeconomic impact on device-associated infections in pediatric intensive care units of 16 limited-resource countries: International Nosocomial Infection Control Consortium findings. Pediatric critical care medicine 13(4): 399-406.

53. Wagenvoort J, Sluijsmans W, Penders R. 2000. Better environmental survival of outbreak vs. sporadic MRSA isolates. J Hosp Infect 45(3): 231-234.

54. Kramer A, Schwebke I, Kampf G. 2006. How long do nosocomial pathogens persist on inanimate surfaces? A systematic review. BMC Infect Dis 6: 130 .

55. Han J, Sullivan N, Leas B, Pegues D, Kaczmarek J, Umscheid C. 2015. Cleaning Hospital Room Surfaces to Prevent Health Care-Associated Infections: A Technical Brief. Ann Intern Med 163(8): 598-607.

56. Allen M, Hall L, Halton K, N Graves., 2018. Improving hospital environmental hygiene with the use of a targeted multimodal bundle strategy. Infection, Disease \& Health. Vol 23, (2), PP 107-113.

57. Dancer S. 2009. The role of environmental cleaning in the control of hospital-acquired infection. J hospital infect 73(4): 378385.

58. Siani H, Maillard J. 2015. Best practice in healthcare environment decontamination. Eur J Clin Microbiol Infect Dis 34(1): $1-11$.

59. Empaire G, Guzman Siritt M, Rosenthal V, Perez F, Ruiz Y, Diaz C, Di Silvestre G, Salinas E, Orozco N. 2017. Multicenter prospective study on device-associated infection rates and bacterial resistance in intensive care units of Venezuela: International Nosocomial Infection Control Consortium (INICC) findings. Int Health 9(1): 44-49.

60. 1997. Management of health care workers infected with hepatitis B virus, hepatitis $\mathrm{C}$ virus, human immunodeficiency virus or other bloodborne pathogens. Infect Control Hosp Epidemiol 18:347-363

\section{REFERENCES OF FIGURES AND TABLES}

Figure 1

Neonatal intensive care unit (NICU), King Abdulaziz University hospital, Jeddah, Saudi Arabia.

Figure 2 
Kirk, J., Kendall, A., Marx, J., Pincock, T., Young, E., Hughes, J., \& Landers, T. 2016. Point of care hand hygiene-—where's the rub? A survey of US and Canadian health care workers' knowledge, attitudes, and practices. Am J Infect Control 44(10): 10951101.

Table1 : Wilson, A., \& Nayak, S. 2013. Disinfection, sterilization and disposables. Anaesthesia \& Intensive Care Medicine 14(10): 423-427. 